\title{
THE EMPOWERMENT OF COMMUNITY BY C-KIP TO IMPROVE THE SLUMS
}

\author{
Dewi Septanti
}

Department of Architecture, Institut Teknologi Sepuluh Nopember, Surabaya

Indonesia

e-mail: dewi_s@arch.its.ac.id

\begin{abstract}
Surabaya has long term experience in conducting slum upgrading program. Started from colonial era which known as KIP Verbetering until the most recent one, called KIP program (Comprehensive - KIP which was funding by Indonesian government). The last program tried to involve community participation by using Three Empowerment (Tri Daya) sustainability scheme : Environmental, Social, and Economic. People can participate as the decision maker, implementer or supervisor in this program. Based on this scheme, the C-KIP model spread its successes through the country and across the developing world.

The combination between research and design methods, where the research strategy is using qualitative strategy is the method which used in this study. The data collection techniques are using documentation observation and stakeholders interview (community, facilitator and government).

By empowering community's capacity, government had many advantages such as getting people to be more attentive to the program, reaching maximum result with a small budget, the implementation and monitoring program can be done by community, involving more people in getting benefits from the program, making room for people to participate and be responsible to take care of the program, etc.
\end{abstract}

Keywords : Kampung Improvement Program, Community Empowerment, Community Participation

\section{INTRODUCTION}

Indonesia, like many other of developing countries (DCs), has to face a rapid growth of cities, which leads to social problems as well as serious burdens for man and the environment (UN-HABITAT and GUO, 2003). This can also be noticed in the conditions of the settlements in big cities that become slums, which are more than often improper for habitation. Moreover, this condition has worsened because of the lack of infrastructure, services, physical facilities and clean water. In order to 
improve the quality of human life in the slums, Surabaya conducted the slum upgrading program called Kampung Improvement Program (KIP) to improve the quality of physical condition.

Surabaya is the second largest city in Indonesia with a total population 3.5 million which are divided into 163 sub-district. The birth rates and high urbanization led to the increase of urban growth which in turn impact the high demand for housing and infrastructure. Housing backlog continues to increase every year causing some areas to grow into slums (Surabaya and Figures, 2010).

In order to decrease the problems in the slums, notably the lack of facilities and infrastructure, as well as an effort to improve the local economy, Surabaya conducted kampung improvement program which known as Kampung Improvement Program (KIP). Kampung Improvement Program (KIP) is a neighborhood improvement program implemented in low-income regions (villages) in the cities in Indonesia (Silas, 1992, 2001, 2003). Kampung Improvement Program (KIP) is the first successful and globally recognized slums upgrading program which held in Surabaya. This scheme was duplicate in many other developing countries which adapted by their local condition (UN-Habitat, 2012).

During the development of KIP, it has a variety of funding schemes and portion of people participation in the implementation. Starting from a complete lack of community involvement to a full participation from the beginning of the program until monitoring activities. The implementation of KIP can not be separated from the political situation in this country. The development of community understanding and knowledge require the governments to involve the community in the implementation of this program.

\section{THEORY / RESEARCH METHODS}

The combination between research and design methods, where the research strategy is using qualitative strategy is the method which used in this study. The data collection techniques are using documentation observation and stakeholders interview (community, facilitator and government). The analysis technique is using qualitative descriptive. The time sequel method and comparative analysis between community participation, the program and product will be analyse in order to gain the overview and development concept of community participation in Kampung Improvement Program in Surabaya.

\section{The History of Slums Upgrading Program in Surabaya}

The historical method used to identify and determine the case and phenomena that have been happened in the time series during occupation. The problem and how to solved, have been describe as the time sequenced of the programs that have already done (Knight, 2016). First of all, starting from beginning, the first slum upgrading program in Surabaya was launched in the colonial era, called KIP Verbetering. The purpose of this KIP was to protect kampong from pest disease that was caused by 
rats. In terms of community involvement, it was non-existent at that time. Everything has been arranged and financed by the colonial government. Moreover, Indonesia was under the grip of the invaders, therefore almost all of the community's aspiration or public opinion had been ignored. After Independence Day, Surabaya carried out the slum upgrading program known as KIP WR Supratman. This type of KIP let community support half of financial program. This pattern indicates that the program involved a high level of community participation at the local level. W.R Supratman KIP is one of the city's maintenance stages that was carried out by the Government of Surabaya and was conducted based on the proposal from the residents of kampungs. This proposal is the result of deliberation of the residents who have a desire to improve their own environment and with the direction and guidance of the Regional Government of Surabaya in solving problems that might arise (Sunarti, 1983 in Dianingrum et.al 2016).

KIP first generation started in 1979 called the Kampung Improvement Program (Kampung Improvement Program / KIP) funded by World Bank by using the top-down schemes, namely the initiation and decisions and decision made by the government as the owner of the policy. In this program, people just accept the program that has been determined by the government. Even though the community involvement existed, the scale was limited. People were much more involved during implementation, but not for decision-making.

In 1998, Indonesia was hit by financial crisis and the change of national leadership. This also affected the scheme of C-KIP implementation which was held in Surabaya. However, although people suspected and distrusted the government, they still trust the higher education. This situation had caused universities to become the facilitator of community to implement the program. The proportions of community participation were further improved. C-KIP resumed in 2001 after stopping for three years as the impact of the financial crisis. The program which started in this year was better known as the Comprehensive KIP (C-KIP) second generation. This program was financed by the city government of Surabaya. The program tries to involve community participation in every activity. There are 3 Empowerment (Tri-Power or Tri Daya) of citizens applied to the implementation of this program: Environmental, Social, and Economic. The concept of Tri Daya will be discussed in a separate sub-chapter. Under this scheme, the success of C-KIP Model spread in developing countries around the world and some of them adopting the C-KIP system.

In addition to the Comprehensive KIP program, Surabaya also carry out some other programs that also aim to improve the physical environment by including public participation, such as Social Rehabilitation of Slums Area (RSDK) program, Co-Bild, Program for Reducing the Urban Poor (P2KP), etc, With the existence of these several kinds of programs, Surabaya gets so much cleaner that it becomes one of the main reference for other cities in repairing of the village that promotes community involvement in the planning, implementation, monitoring, and evaluation. 
Of the 163 existing kampongs, since 1998, the second generation of C-KIP has been executed in almost 69 sub districts, which can be seen in Figure 1.

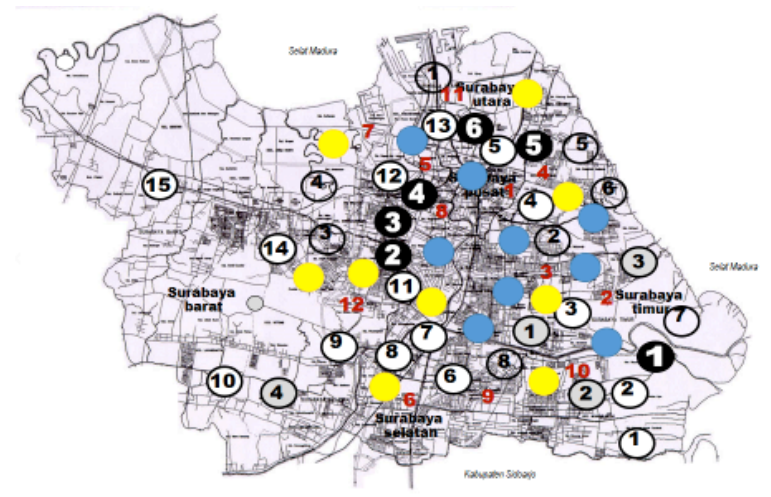

Figure 1. The location of C-KIP program implementation di Surabaya in 1998 - 2004 Source : Technical Guidance of C-KIP 2001-2004

There are 69 out of 163 kampungs (42.33\%) in Surabaya, that has received this program, until the pattern changed into the new one : "the Kampung Unggulan". In the implementation of the second-generation C-KIP, the citizens are given a greater chance of participation in planning / preparation, implementation, and evaluation of the program.

\section{The Development of Community Empowerment Scheme on C-KIP Program}

As mentioned before, there are three empowerments of citizens contained in Kampung Improvement Program. This program is an integrated kampong development that is seen as an interrelated processes of the social, economic, and physical environment based on the participation of the dweller during its process (CKIP Implementation Guide, 2001). This program takes precedence on the empowerment of citizens in all spheres. Through community participation, it is expected that people would feel better in having this program being carried out in their neighborhood and to be actively involved in the planning, implementation, evaluation for future sustainability. The relationship between the three powers can be explained in Figure 2: 


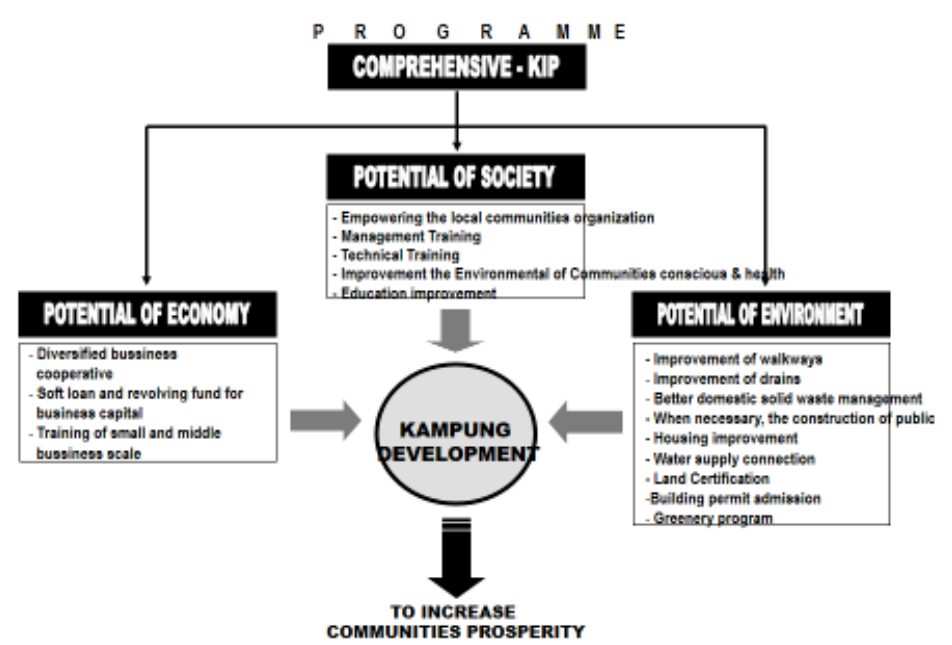

Figure 2. The scheme of community empowerment in the second generation of C-KIP Source : Technical Guidance of C-KIP 2001-2004

To understand the relationship among these empowerments, the three of them will be explained below. Social empowerment includes empowering the community by:

1. Strengthening the organization which set up in the local community, in this case, the Kampung Foundations, Cooperatives and Self-help community groups (KSW).

2. Improvement the capabilities of community's managerial by training them with special workshops for institutional management.

3. Technical training to enhance the ability of individual capability in accordance with the needs of each personal (a revolving loan fund that the acceptor should be the member of KSW).

4. Improving the quality of the environment in order to improve the health.

Community empowerment in the economic field activities include:

1. Establishment of institutional financial manager (Cooperative)

2. The revolving soft loan for working capital

3. Training for small and medium enterprises.

Neighborhood empowerment of activities include, among others:

1. Improved roads, sanitation, solid waste management

2. Improved physical quality public facilities

3. Improving the quality of housing.

4. Installation of water

5. Handling the ownership of land and buildings

6. Management building permits. 


\section{How Community Can be Participate to Support the Program Fund}

As previously mentioned, the implementation of C-KIP began in 2001, while the funding was borne entirely by the government of Surabaya. The amount of funds granted to each village is Rp. 200.000.000, - (for comparison that the price of rice in 2001 is Rp. 2,500 / kg, and as of this writing (2016) is Rp. 12,000/ kg), while in the following years donated funds amounting to Rp. 250.000.000, -

While the government has provided the funding for the implementation of the program, but people still can contribute to support of the government funding. Due to gain the successful program in community, the community participation is required. The participation can be seen as in the Tabel 1:

Tabel 1. The composition of funding and the possibilities of community to participate

\begin{tabular}{lllll}
\hline PROGRAM & & $\begin{array}{l}\text { Grant } \\
(\%)\end{array}$ & $\begin{array}{l}\text { Revolving } \\
(\%)\end{array}$ & $\begin{array}{l}\text { Community } \\
\text { Participation }\end{array}$ \\
\cline { 2 - 4 } Physical & Physical Env. Improvement & 15 & & Yes \\
Aspect & $\begin{array}{l}\text { Greenery \& Cleanliness } \\
\text { Housing Improvement }\end{array}$ & 7.5 & & Yes \\
Community & Arranging local institution & 7.5 & 30 & Yes \\
Development & $\begin{array}{l}\text { Training for community } \\
\text { Micro }\end{array}$ & & 10 & Yes \\
Economic & Small and medium scale & & 30 & Yes \\
buss. capital & \multicolumn{2}{c}{ Source: Technical Guidance of C-KIP 2001-2004 } \\
\hline
\end{tabular}

People can give their contribution in almost all of the program. They can participate in physical aspect, community development and micro economic. Whether it as money, material, labor, assistance or moral supported, this contribution can be mentioned as community participation.

\section{Community Can be Participate as the Member of KIP Institution}

In Kampungs community, there are some local institutions that already exist. The existence of these local institutions was initiated by their own or local government. Some institutions were built through community initiation, such as: recitation, savings and loans groups, youth groups, reading Qur'an group etc. While the other institutions stand at the initiative of the government (because it must exist in every kampong), for example LKMK, RT (local community institution) / RW (neighborhood community institution), etc. In preparation for the implementation of the KIP, three types of agencies in the community which is a fusion of the existing institutions has established. These institutions that established to support the implementation of the KIP are Kampong Foundation (YK), cooperatives and Community Self-help Group (KSW). The three institutions are complementary, coordinative and will supervise each other. Here are the institutions in community before and after the implementation of the C-KIP (see Tabel 2). 
Tabel 2. Existing Local Institution and its form in C- KIP

\begin{tabular}{|c|c|c|c|}
\hline $\begin{array}{l}\text { Present } \\
\text { Organization }\end{array}$ & Function & Form & Scope \\
\hline $\begin{array}{l}\text { LKMD } \\
\text { Women } \\
\text { Organization }\end{array}$ & $\begin{array}{l}\text { Institution } \\
\text { Coordinator for } \\
\text { comprehensive } \\
\text { program }\end{array}$ & $\begin{array}{l}\text { KAMPONG } \\
\text { FOUNDATION } \\
(Y K)\end{array}$ & $\begin{array}{l}\text { Established by communities } \\
\text { in sub district level } \\
\text { Coordinate the } \\
\text { comprehensive program and } \\
\text { KSM's activities }\end{array}$ \\
\hline $\begin{array}{l}\text { Youth } \\
\text { Organization } \\
\text { NGO }\end{array}$ & $\begin{array}{l}\text { Funding } \\
\text { Institution }\end{array}$ & $\begin{array}{l}\text { DIFERSIVIED } \\
\text { BUSSINESS } \\
\text { CO-OPERATION }\end{array}$ & $\begin{array}{l}\text { Established by communities } \\
\text { in sub district level } \\
\text { Manage the funding of } \\
\text { Kampong dev. program }\end{array}$ \\
\hline $\begin{array}{l}\text { Reading } \\
\text { Qur'an Group } \\
\text { Revolving } \\
\text { Fund Group }\end{array}$ & $\begin{array}{l}\text { Aspirator } \\
\text { institution \& } \\
\text { Technical } \\
\text { implementation }\end{array}$ & $\begin{array}{l}\text { COMMUNITY } \\
\text { SELF-HELP } \\
\text { GROUP }(K S W)\end{array}$ & $\begin{array}{l}\text { Established by communities } \\
\text { in RT level, } \\
\text { Each group has about } 6-10 \\
\text { person as members }\end{array}$ \\
\hline $\begin{array}{l}\text { Mass } \\
\text { Organization } \\
\text { Posyandu } \\
\text { Treatment } \\
\text { Group }\end{array}$ & $\begin{array}{l}\text { Sub } \\
\text { Coordinator } \\
\text { Program }\end{array}$ & $\begin{array}{l}\text { The Committee } \\
\text { of Community } \\
\text { Self-Help Group } \\
(B K-K S M)\end{array}$ & $\begin{array}{l}\text { Established by KSM in RW } \\
\text { level, } \\
\text { consist of several KSM in } \\
\text { that level }\end{array}$ \\
\hline
\end{tabular}

Institutions that make decisions are not the holder and executor of the fund, while the holder of the funds is not the decision maker nor the executor, and the institutions that execute are not decision makers and holders of the funds. Figure 3 shows the relationship between organizations / institutions on Village Development Agency on C-KIP program:

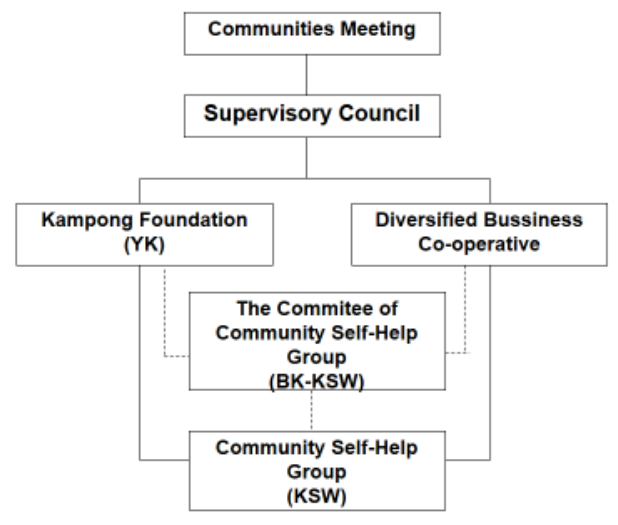

Figure 3. The link among Organization in Kampung Development Board (BPK) 


\section{Community Participation in Every Stages of C-KIP Implementation}

Practically there are several stages of implementation that can be divided into 3 phases, namely the preparation, the implementation and the monitoring and evaluation stage where people can be participate in this program. All of the stages and what people contribute will be explained below:

\section{Preparation Stage}

The preparation stage includes several activities, such as :

1. Socialization of programs to the affected communities. The purpose and objectives of socialization is to let the people know earlier about the program that will be implemented in their kampong.

2. The explanation and preparation of Community Mapping (mapping by society). Community mapping contains the assessment points of the environmental conditions and existing facilities in an area. In the implementation of C-KIP, Community mapping is carried out at the neighborhood level by involving the community to fill it. Community can give their active contribution during community mapping as the basic resource to decision making.

3. Workshop on the Concept C-KIP explanation, and prepare guidebooks manual. This workshop is important so that people will have an idea of the C-KIP 's programs before the execution. The workshop will prepare people to be ready and understand the program before implementation. So that, community participation will increase when the implementation stage.

\section{Implementation Stage}

The implementation stage includes several activities such as :

1. The implementation of community-based mapping (Community Self-Mapping). At this stage, the society (in this regard, RT) conducting a survey of environmental conditions in their living area by following the items listed on community mapping.

2. Formation of Village Development Agency (BPK). CPC is an institution that was set up at the village comprising Kampong Foundation; Cooperatives and Community Self-Help Group (KSW). As explained earlier, the three institutions are directly responsible for the implementation of the C-KIP. As a mean to bring together the various elements that already exist in the community before, these three components are the embodiment of the village community as a whole.

3. Institutional Training. Institutional training conducted after the formation of the three institutions in this KIP program, because this training is intended for the managers of the institution in order to run this program properly as expected.

4. Establish and identify the membership of Community Self-Help Group (KSW).

5. KSW members are formed after YK and Cooperative are formed. The program is determined by the establishment of physical and un- physical programs to be executed by the community. Kampong Foundation is the leader of the 
deliberation regarding the program that will be implemented in the implementation stage. Before meeting in sub-district level, community, and their local neighborhood has to have decided the kind of program that will be proposed to fund this program. The previous community meeting is led by RW and is done beyond the local level.

6. Agreement program implementation plan. The purpose of this consultation at RW level is to agree on proposals to be submitted in the deliberations held at the village, led by the Chairman of the Foundation Village.

7. Disbursement of a revolving loan fund to members of KSW. After the agreements are made between the residents of Kampong Foundation, the funding is disbursed. It is hoped that the public can use the money for purposes that are very urgent.

8. Implementation of the physical and non-physical program. The activities components in C-KIP program can be divided into two types, namely: (1) Physical Program. Improvement of physical environment which includes the following activities: the improvement of paving part (pedestrian way), cleaning the gutter, etc. Greening and cleaning (procurement of garbage bin, planting medicine plant, making a garden, etc.). (2) Non-Physical Program. Resource Development (Society), an increase in human resources through vocational trainings such as: driving, sewing, etc. Enhanced Small and medium-sized businesses (business management training, revolving soft loans) with the aim to improve economic opportunities and increase revenues. Improving the Quality House Live (in the form of a revolving soft loan to repair the physical home, running water connections, building permits, ownership, etc.)

\section{Monitoring and Evaluation Stage}

In the monitoring and evaluation stage, people are also involved in some activities that require them to participate, for example:

1. Monitoring and supervision in the field. Monitoring and evaluation have been done by the community, especially if they are directly involved. Besides the community, monitoring was also conducted by facilitators and State Supervisory Board teams.

2. Report and Evaluation of Program Implementation. Reporting is common to show the progress of the program and it should be drafted as one of the obligations to report on the implementation and results of the programs which are carried out.

\section{CONCLUSIONS AND SUGGESTION}

Relevant with the implementation of community-based development concept (the development which focused on the community), the organization of community's activities has a very important role because the people are involved in almost all stages of the program. People are required to engage actively and get involved to 
ensure the success of this program, ranging from planning, implementing, monitoring and maintenance until the results of the implementation of the program's sustainability.

Based on the evaluation of the implementation of the Comprehensive KIP since 1998 - 2006, community participation is a key factor to support this program. By using the involvement of community into the program, both governments, and communities gain a lot of advantages, such as:

1. People are more attentive to the program,

2. The maximum result can be reached with a small budget,

3. The implementation and monitoring program can be done by community,

4. Involved more people in getting benefit from this program,

5. People can participate and be responsible to take care of the program, etc.

\section{REFERENCES}

Dianingrum, et . al (2016), Perkembangan Program Perbaikan Kampung di Surabaya dan Pemberdayaan Masyarakat, Thesis, Pasca Sarjana Arsitektur ITS.

Septanti, D. (2004), Micro Credit System for Housing Finance in ComprehensiveKIP and Social Rehabilitation on Slums Area Program in Surabaya CIB Journal ; Vol. 302 The Netherlands - 2004.

Septanti, D (2004), Comparative Study for The Implementation of C-KIP between Urban Sub-District and Coastal Sub-District Jurnal Rekayasa Perencanaan Vol. 1 No.1 Oktober 2004 ; ISSN 1829-913 X - FTSP UPN Veteran Jawa Timur

Dinas Tata Kota Surabaya, (2001), Technical Guidance of C-KIP, year 2001

Dinas Tata Kota Surabaya (2002), Technical Guidance of C-KIP, year 2002

Dinas Tata Kota Surabaya (2003), Technical Guidance of C-KIP, year 2003

Dinas Tata Kota Surabaya. (2004), Technical Guidance of C-KIP, year 2004

Knight, J, Gharipour Urban Displacement and Low Income Communities : The Case of The American City from The Late Twentieth Century. Archnet-IJAR (serial online). July 2016: 10(2): 6-21

Silas, J., 2003. Kampung and Informal Settlements in Indonesia.

Silas, et.al (2010), Surabaya's Kampung toward the 21 th Century, Bappeko Surabaya.

Silas (1988), KIP, A Decade of Kampung Improvement Program Implementation in Surabaya in 1976 - 1986; Pemerintah Daerah Tingkat II Kotamadya Surabaya.

UN-HABITAT, 2003. Slums of the World: the Face of Urban Poverty in the New Millennium. United Nations for Human Settlements.

UN-HABITAT, 2008. Housing for All: The Challenges of Aff ordability, Accessibility and Sustainability, 978-92-1-131992-7. United Nations Human Settlements Programme, Nairobi.

Surabaya dalam Angka, 2010 